УДК 005.334:658.15

DOI: $10.25140 / 2411-5215-2020-1(21)-267-284$

Олена Шиикіна

\title{
ЗАКОНИ Й ЗАКОНОМІРНОСТІ УПРАВЛІННЯ ФІНАНСОВИМИ РИЗИКАМИ ПРОМИСЛОВИХ ПІДПРИЕМСТВ
}

\author{
Елена Шишкина
}

\section{ЗАКОНЫ И ЗАКОНОМЕРНОСТИ УПРАВЛЕНИЯ ФИНАНСОВЫМИ РИСКАМИ ПРОМЫШЛЕННЫХ ПРЕДПРИЯТИЙ}

\author{
Olena Shyshkina \\ LAWS AND REGULARITIES OF FINANCIAL RISK MANAGEMENT \\ OF INDUSTRIAL ENTERPRISES
}

\begin{abstract}
У статті досліджено термінологічний апарат таких категорій, як «закон» $i$ «закономірність» та встановлено зв'язки між ними. Доведено, щзо розкрити зміст методології управління фінансовими ризиками промислових підприємств, не застосовуючи закони різних рівнів пізнання (універсальні, загальні й часткові), неможливо. У зв'язку з иим розкрито змістовну сутність універсальних, загальних $і$ часткових законів, законів, що є описовими й пояснюючими, законів, які є статистичними та динамічними, законів, які носять фундаментальний та прикладний характер, $\epsilon$ феноменологічними й есенціальними, а також законів побудови, функиіонування та розвитку систем. Визначено роль $i$ місие законів управління в системі законів, сформульовано сутність законів управління фінансовими ризиками. Узагальнено основні методи дослідження проблеми управління фінансовими ризиками промислових підприємств $і$ сформульовано зміст основних законів та закономірностей управління фінансовими ризиками промислових підприємств.

Ключові слова: фінансовий ризик; управління фінансовими ризиками; закони; закони управління; закони побудови; функціонування і розвитку; закономірності управління; промислові підприємства.

Рис.: 4. Бібл.: 38.

В статье был исследован терминологический аппарат таких категорий, как «закон» и «закономерность» и установлены связки между ними. Доказано, что раскрыть содержание методологии управления финансовыми рисками промышленных предприятий не применяя законы разных уровней познания (универсальные, общие и частные) невозможно. В этой связи, раскрыта содержательная сущность универсальных, общих и частных законов, законов, которые являются описательными и объясняющими, законов, которые являются статистическими и динамическими, законов, которые носят фундаментальный и прикладной характер, являются феноменологическими и ессенциальными, а также законов построения, функиионирования и развития систем. Определены роль и место законов управления в системе законов, сформулирована роль законов управления финансовыми рисками. Обобщены основные методы исследования проблематики управления финансовыми рисками промышленных предприятий и сформулировано содержание основных законов и закономерностей управления финансовыми рисками промылиленных предприятий.

Ключевые слова: финансовый риск; управление финансовыми рисками; законы; законы управления; законы построения; функиионирования и развития; закономерности управления; промышленные предприятия.

Рис.: 4. Библ.: 38.

The article explores the terminological apparatus of such categories as "law" and "regularity" and establishes links between them. It has been proved that it is impossible to disclose the content of the methodology of financial risk management of industrial enterprises without applying the laws of different levels of knowledge (universal, general, and partial). In this connection, it has been disclosed the substantive essence of universal, general, and partial laws, the laws that are descriptive and explanatory, the laws that are statistical and dynamic, the laws that are fundamental and applied, the laws that are phenomenological and essential, and the laws of systems formation, functioning and development. The role and place of management laws in the system of laws have been determined and the role of financial risk management laws has been formulated. The basic methods of the research of problems of financial risk management of industrial enterprises have been summarized and the content of the basic laws and regularities of financial risk management of industrial enterprises has been formulated.

Keywords: financial risk; financial risk management; laws; laws of management; laws of formation; functioning and development; regularities of management; industrial enterprises.

Fig.: 4. References: 38.

JEL Classification: D81; G32

Постановка проблеми. В умовах трансформаційних змін, що характерні для нестаціонарної економіки України, проблема забезпечення стійкого функціонування промислових підприємств - основи реального сектору національної економіки, набуває надзвичайної актуальності. Стійкий характер життєдіяльності будь-якого підприємства визначається ефективністю його операційної, фінансової та інвестиційної діяльності, а конкурентоспроможність та інвестиційна привабливість таких підприємств безпосередньо залежить від їхньої здатності запроваджувати інновації в бізнес-процеси.
\end{abstract}

(с) Шишкіна О. В., 2020 
ФІНАНСОВІ РЕСУРСИ: ПРОБЛЕМИ ФОРМУВАННЯ ТА ВИКОРИСТАННЯ

Управління ефективністю підприємства значним чином визначається здатністю протидіяти загрозам зовнішнього і внутрішнього середовища, що спричинюють ризики, які здатні призвести до певних фінансових втрат, які вимірюються прибутком (доходом, капіталом), тобто можуть слугувати джерелом відповідно допустимих, критичних або катастрофічних за наслідками ризиків. Таким чином, управління промисловим підприємством необхідно пов'язувати з управлінням його фінансовими та іншими видами ризиків.

Результативність управління фінансовими ризиками промислового підприємства як складної динамічної системи, що змінюється в процесі виконання своїх тактичних завдань і стратегічних планів, визначається здатністю врахувати наявні взаємозв'язки й залежності між складовими елементами зазначеної системи.

Розуміння законів, закономірностей та принципів управління фінансовими ризиками дозволить більш грунтовно дослідити зв'язки між елементами системи ризикменеджменту промислового підприємства, простежити постійні, тимчасові та випадкові зв'язки, сприятиме своєчасній ідентифікації, аналізу й оцінці ризиків, а також розробці й запровадженню комплексу антиризикових заходів. Тим самим, дослідження законів, закономірностей і принципів управління фінансовими ризиками промислових підприємств є дуже необхідним в умовах нестаціонарної економіки України, що зумовлює актуальність обраної наукової теми.

Аналіз останніх досліджень і публікацій. Фундаментальні положення у сфері дослідження складних систем, системного аналізу, процесів функціонування та розвитку систем і системних утворень присвячені роботи М. Амосова [4], С. Біра [6], В. Ешби [1], Н. Коршунової [15], Ф. Константінова [14], Д. Новікова [17; 18], В. Осіпова [19], I. Прангішвілі [22], Х. Сільви [26], Р. Стоуна [26], В. Шарапова [32] та багатьох інших. Теоретико-методологічним основам управління підприємствами присвячена значна кількість робіт вітчизняних і закордонних учених, а саме: Б. Андерсена [5], П. Браунерхельма [2], Ю. Валуєва [7], В. Еліферова [24; 25], Г. Кокінза [13], М. Портера [21], В. Рєпіна [24; 25], М. Фельдмана, В. Шарапова [32], Й. Шумпетера [36] та ін.

Концептуально-прикладні основи управління промисловими підприємствами знайшли відображення в наукових доробках Т. Бартона, С. Бєлова, М. Володькіна [8], В. Жарікова, Г. Клейнера, Г. Козаченко [30], У. Шенкира, А. Шеєра [33], В. Туркіна, П. Уокера та ін.

Проблемі управління ризиками підприємств загалом і промислових підприємств, зокрема, присвячували свої доробки такі вчені, як А. Альгін, І. Бланк, І. Балабанов, Н. Внукова, П. Вітлінський, П. Грабовий, В. Гранатуров, М. Лапуста, Б. Лагоша, О. Йода, Н. Злобіна [10], Н. Капустіна [12], О. Лобанов, Є. Хрустальов, В. Лівшиць, А. Старостіна, Р. Сніщенко [28], А. Фомічов [31] та ін.

Багаторічна напружена праця науковців і практиків у сфері управління підприємством загалом і його ризиками зокрема ознаменувалась створенням стандартів ризикменеджменту, а узагальнення світового досвіду в досліджуваній сфері створило підстави для розробки й запровадження в практику господарювання рекомендацій під назвою «Управління ризиками підприємства - інтегрована структура», які вперше були опубліковані у 2004, а згодом у 2017 р були розповсюджені в такій редакції: «Управління підприємством - інтеграція із стратегією та ефективністю продуктивності» [3; 33].

Використання вказаних та інших документів у практиці господарюючих суб'єктів дало змогу певним чином мінімізувати негативні наслідки ризиків, які отримали відображення у вигляді певних фінансових втрат (збитків).

Виділення недосліджених частин загальної проблеми. Незважаючи на широкий науково-практичний інтерес до питань управління промисловим підприємством загалом та проблемі управління ризиками, що виникають у процесі операційної, фінансової та інвестиційної діяльності зазначених підприємств, у науковій літературі недостатньо 
ФІНАНСОВІ РЕСУРСИ: ПРОБЛЕМИ ФОРМУВАННЯ ТА ВИКОРИСТАННЯ

уваги приділяється використанню законів і закономірностей управління, які дозволили би краще зрозуміти взаємозв'язок різних видів діяльності, вплив зовнішнього та внутрішнього середовища на стійке функціонування та розвиток або санацію чи відновлення діяльності суб’єктів господарювання.

Розуміння закономірностей управління процесами функціонування та розвитку та врахування дії законів управління дозволить максимально результативно вирішити нагальні проблеми, що постають перед функціонуючим суб'єктом пов'язаних з пошуком шляхів мінімізації ймовірних фінансових втрат від прояву різних видів ризиків. Вищезазначене дозволяє сформулювати мету і завдання цього наукового дослідження.

Метою статті $\epsilon$ визначення основних законів і закономірностей управління фінансовими ризиками у контексті забезпечення стійкого функціонування та розвитку промислових підприємств.

Досягнення означеної мети потребує поступового вирішення таких теоретикометодологічних завдань:

- визначення термінологічного змісту таких категорій, як «закон» і «закономірність» та встановлення зв'язків між ними;

- розкриття змістовної сутності основних законів і закономірностей управління фінансовими ризиками промислового підприємства в умовах посилення зовнішніх і внутрішніх загроз його функціонуванню і розвитку.

Виклад основного матеріалу. Врахування законів і закономірностей управління фінансовими ризиками в процесі досягнення економічним суб'єктом його тактичних та стратегічних планів насамперед потребує від науковця розуміння сутності цієї категорії.

Під «категоріями» будемо розуміти «...ннайбільш загальні фундаментальні поняття тієї чи іншої науки» [29, с. 262], які за своїм сенсом є більш глобальними, аніж «поняття».

Зазначимо, що саме в категоріях і поняттях уособлюються знання людства про навколишнє середовище (явища, процеси, предмети тощо). Людина в повсякденному житті та своїй професійній діяльності думає різного роду категоріями, тобто загальними поняттями. Отже, і категорії, і поняття є необхідними складовими елементами людського мислення, пізнання властивостей предметів та взаємозв'язків їхніх характеристик і ознак, відносин з іншими предметами, дослідження процесів функціонування та розвитку певних явищ і процесів.

Кожна галузь знань базується як на загальних, властивих будь-якій науці, так і на специфічних, притаманних лише їй категоріях. Отже, вивчаючи особливі зв'язки явищ, що існують в тій чи іншій сфері дійсності, необхідно досліджувати питання взаємодії області, що досліджується та іншими областями (галузями, сферами) діяльності.

Вирішуючи певну науково-прикладну проблему вчений досліджує причинні відносини у своїй сфері, наприклад, фінансист досліджує зв'язок необоротного й оборотного капіталу підприємства та джерел їх формування (власного і позикового капіталу), ризик-аналітик вивчає схильність певного суб'єкта до ризику залежно від зміни зовнішнього і внутрішнього середовища, ризик-менеджер узагальнює ризик-формуючі фактори, ідентифікує ризики, досліджує їх взаємозв'язок і взаємозалежність, аналізує і оцінює їх вплив на фінансові втрати суб'єкта підприємницької діяльності та розробляє програму дій щодо мінімізації негативного впливу ризиків і загроз на його функціонування і розвиток тощо.

Вивчаючи певні категорії, що відображують навколишнє середовище досліджуваного суб'єкта в процесі його практичного перетворення, науковець здатен більш глибоко розвити своє мислення в досліджуваній галузі знань. Тобто «... категорії стають засобом пізнання дійсності з метою ії подальшого більш широкого і більш глибокого перетворення» [29, с. 263]. 
ФІНАНСОВІ РЕСУРСИ: ПРОБЛЕМИ ФОРМУВАННЯ ТА ВИКОРИСТАННЯ

Тобто використовуючи категорії «фінансовий ризик», «промислове підприємство», «функціонування», «розвиток» і таку систему категорій, як «причина», «наслідок», «форма», «зміст» та інші, ми можемо більш глибоко дослідити понятійний апарат наукової проблеми, яка досліджується в нашій науковій роботі, обгрунтувати методологію дослідження. При цьому необхідно, з одного боку, усвідомлювати факт стійкості (з позицій назви) таких категорій, як «фінансовий ризик», «управління» та інші, а з іншого прийняти мінливість і змінність зазначених категорій приналежно, наприклад, часових кордонів їх вивчення, об'єкта дослідження (промислове підприємство, банківська установа, страхова компанія і т. ін.) та стадії його життєвого циклу (наприклад, народження, зростання, стабільне функціонування, старіння, відродження), структурних складових процесів у межах яких ведеться дослідження (наприклад: становлення, функціонування, розвиток, банкрутство, санація, ліквідація тощо).

Ретроспективний погляд на видозмінення певної категорії через призму узагальнення різного роду наукових досліджень дозволяє проаналізувати певні тенденції змін, сформулювати закони, які є «...результатом відображення об'єктивного світу у процесі його практичного перетворення» [29, с. 263] і визначити закономірності таких перетворень.

Розкрити зміст методології управління фінансовими ризиками промислових підприємств, не застосовуючи відповідні категорії, неможливо, оскільки саме вони дозволять визначити сучасний рівень протидії фінансовим та іншим ризикам, оцінити результативність ризик-менеджменту на відповідній стадії життєвого циклу досліджуваного суб'єкта підприємництва в межах його операційної, інвестиційної та фінансової діяльності та запропонувати ефективний механізм мінімізації негативного впливу ризиків на виконання тактичних і стратегічних планів розвитку.

Використання системи різного роду економічних, філософських, історичних та інших категорій дозволяє охарактеризувати загальний зв'язок і взаємодію об'єктів нашого дослідження, у процесі якого здійснюється поступовий рух від простого до складного, що, по суті, відображає процеси розвитку.

Категорії відображують певні закони, які разом охоплюють різні рівні пізнання (макро-, мезо- і макро-) та відображають ставлення суб'єктів дослідження до зазначених рівнів.

3 філософського погляду закон - це «...категорія, що відображає істотний, необхідний, стійкий, повторюваний (регулярний) зв’язок (відношення) між об'єктами, структурними елементами об'єктів, між явищами різного роду, їх формами, властивостями, процесами, становищем і функціями» [23].

Це «...«необхідний» зв'язок (взаємозв'язок, відношення) між подіями, явищами, а також між внутрішнім станом різних об'єктів, що визначає їх стійкість, виживання, розвиток, стагнацію або руйнування ... це об'єктивні зв'язки явищ і подій, що існують незалежно від того, відомі вони кому-небудь чи ні» [16].

Таким чином, закон характеризує зв'язки між явищами і подіями незалежно від наявності знань і інформації про їх існування, тобто зв'язки, які, по суті, мають обов'язковий характер, але можуть бути необхідними і випадковими. Стійкість і повторюваність відносин і зв’язків вказує на певну послідовність, порядок і тенденції розвитку явищ.

Можна виділити три групи законів:

- універсальні - це закони діалектики, які діють у всіх без винятку сферах діяльності незалежно від численних правил і законів створених людиною. До таких законів відносять такі, які розкривають структуру розвитку на рівні опису самого механізму розвитку (закон єдності й боротьби протилежностей, який розкриває джерело розвитку; закон взаємного переходу кількісних і якісних змін, який дозволяє показати, яким чином відбувається розвиток; закон заперечення заперечення, на основі якого виникає можливість пояснити спрямованість розвитку). А також ті, що пояснюють сутність взаємодії протилежних сторін світу, що розвивається, тобто йдеться про ту частину структури розвитку, яка зумовлює наявність у ньому загальних протилежних сторін; 
- загальні закони не є універсальними, проте відображають зв'язки, які притаманні всім або багатьом формам руху матерії (закони математики, кібернетики, закони збереження енергії тощо);

- часткові закони - притаманні лише певним формам руху матерії та іiї окремим рівням (закони управління, закони механіки, хімії, біології, економіки тощо) (рис. 1).

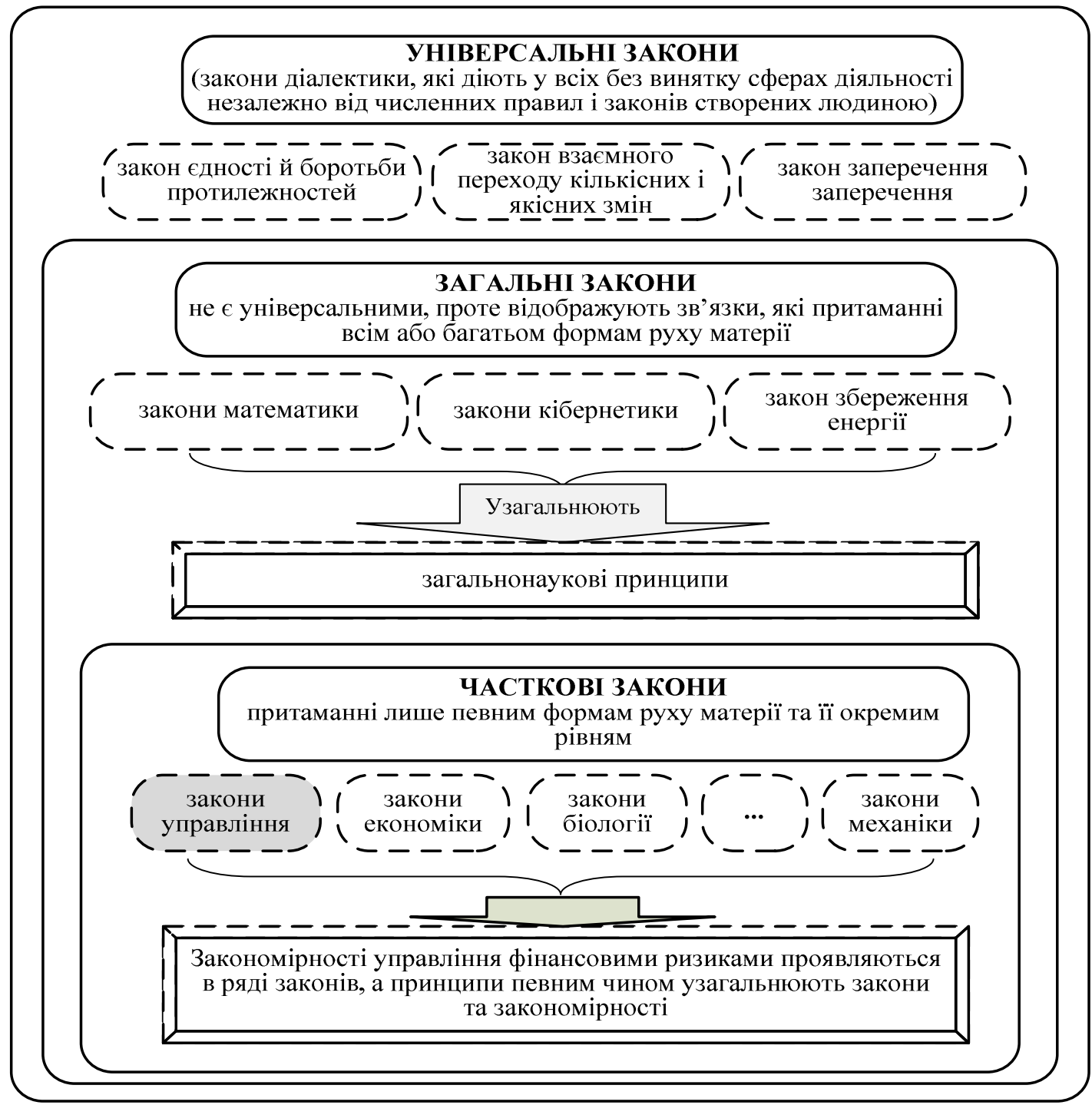

Рис. 1. Іерархія універсальних, загальних і часткових законів, принщипів та закономірностей

Джерело: розроблено автором на основі $[4 ; 6 ; 11 ; 14 ; 16 ; 17 ; 22 ; 23 ; 29 ; 35]$.

Зазначені закони можуть бути:

- статистичними й динамічними.

- описовими й пояснюючими;

- емпіричними й теоретичними;

- феноменологічними й есенціальними (абстрактними);

- фундаментальними та прикладними;

- законами побудови, функціонування і розвитку системи і т. ін. [19, с. 215; 23].

За характером передбачень уся сукупність законів поділяється на статистичні та динамічні. Ці закони посідають особливе місце в наукових дослідженнях, оскільки маючи кількісний вимір і якісну форму прояву, використовуються для вирішення реальних теоретичних і практичних завдань. 
ФІНАНСОВІ РЕСУРСИ: ПРОБЛЕМИ ФОРМУВАННЯ ТА ВИКОРИСТАННЯ

У науковій і методичній літературі склались різні визначення статистичних і динамічних законів, зокрема й ті, що пов'язанні з об'єктами, що описуються. Зокрема, закони, які «...характеризують рух окремих часток називають динамічними, а статистичні це закони, що діють у масі явищ» [19, с. 217].

Динамічні закони дозволяють на підставі знань про певний процес (явище, діяльність, предмет) у контексті співвідношення / поєднання «простір - час» давати однозначні прогнози про інший процес (явище, діяльність, предмет). Тим самим передбачення мають однозначний характер, який можна виразити тезою: «так, а не інакше піде процес розвитку».

Статистичні закони дозволяють на підставі знань про певний процес (явище, діяльність, предмет) 3 урахуванням простору й часу давати імовірнісні передбачення про інший процес (явище, предмет). Оскільки передбачення грунтуються на дії багатьох випадкових факторів і взаємодії значної кількості елементів певної системи, то імовірний характер передбачення можливо описати, як «може бути, а може ні».

Закони можуть носити описовий або пояснювальний характер чи бути есенціальними або феноменологічними. Сутність описового й пояснювального характеру законів повною мірою розкривається сутністю цих понять, які формуються відповідно на описових і пояснювальних гіпотезах. Описові гіпотези економіко-соціологічним словником трактуються як «...припущення щодо фактичного стану об'єкту, який досліджується, його структури та функцій» [37, с. 97]. Пояснювальні гіпотези - це «... припущення відносно причинно-наслідкових зв'язків у досліджуваному об'єкті...» [37, с. 97].

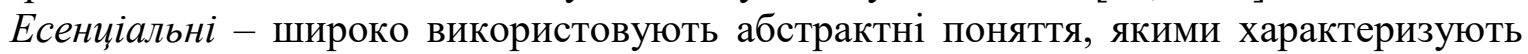
об'єкти за якими йде спостереження. Феноменологічні - виникають на початкових стадіях розвитку науки і з часом поглинаються есенціальними.

Емпіричні закони відображують «стійкі, повторювані зв'язки між емпіричними характеристиками, які часто мають ймовірний характер» [9, с. 22]. Теоретичні закони пов’язують «...особливі абстрактні об'єкти, які створюються з метою ідеалізованого опису і пояснення сутності тих чи інших процесів чи явищ» [9, с. 22].

Емпіричні й теоретичні закони є складовими емпіричних і теоретичних досліджень різних явищ і процесів. А отже, вважаємо доцільним окреслити методи емпіричних $\mathrm{i}$ теоретичних досліджень у сфері управління фінансовими ризиками промислових підприємств, які в поєднанні з математичними методами, що загалом були орієнтовані на узагальнення основних законів, закономірностей і принципів управління ризиками, отримали застосування в цьому дисертаційному дослідженні (рис. 2).

За своєю спрямованістю і відношенню до практики виділяють фундаментальні та прикладні закони $[17 ; 18 ; 19]$. До фундаментальних законів (тобто які не приводяться до інших) належать універсальні закони (зокрема, закони природи, закони всесвіту і т. ін.). Прикладними законами зазвичай є загальні й часткові закони.

Між фундаментальними та прикладними законами прослідковується щільний зв'язок, що реалізується в процесі фундаментальних і прикладних наукових досліджень.

Зокрема, головним завданням фундаментальних досліджень $\epsilon$ «...пізнання законів, які керують взаємодією і поведінкою базових структур природи, суспільства і мислення» $[18$, с. 23]. Ці закони і структури вивчаються безвідносно до їх можливого використання. Зазвичай фундаментальні дослідження випереджають у своєму розвитку прикладні, створюючи для них фундамент з базових законів, закономірностей і теорій [18, с. 23]. Безпосередня мета прикладних досліджень, а нині це близько 80-90 \% від загальної їх кількості, - «...застосування результатів фундаментальних наук для вирішення практичних проблем» [18, с. 23]. Так, більшість технічних, хімічних, біологічних, економічних та інших наук має прикладний характер. 
МЕТОДИ ДОСЛІДЖННЯ ПРОБЛЕМИ УПРАВЛІННЯ ФІНАНСОВИМИ РИЗИКАМИ ПРОМИСЛОВИХ ПІДПРИСМСТВ

Джерело: розроблено автором на основі $[6 ; 9 ; 11 ; 13 ; 17 ; 18 ; 20 ; 22 ; 32 ; 38]$.

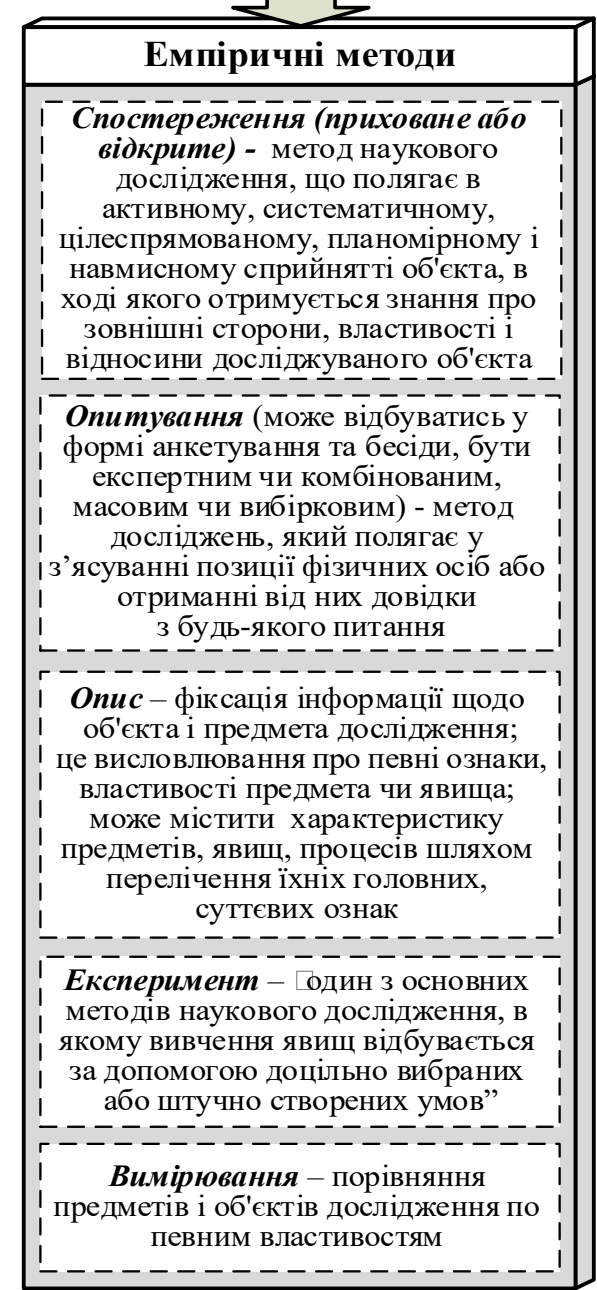


ФІНАНСОВІ РЕСУРСИ: ПРОБЛЕМИ ФОРМУВАННЯ ТА ВИКОРИСТАННЯ

Розвиток прикладних досліджень і запровадження інновацій у всіх видах і сферах діяльності приводить до нагромадження знань, які з часом набувають фундаментального характеру й у певний момент часу виникає ситуація, коли важко розділити прикладні дослідження і фундаментальні, які сформувались на їх основі. Одночасно може виникати й інша ситуація, коли фундаментальні дослідження здатні спричинювати прикладні відкриття.

У цих процесах неабияку роль відіграють процеси управління, від яких, серед іншого, залежить фінансування, планування і контроль наукових робіт та здатність економічних суб'єктів до інноваційного розвитку. Спроможність розвиватися визначається фінансовим, трудовим, виробничим, інноваційно-інвестиційним та іншими видами потенціалу економічного суб'єкта та вмінням топменеджменту розробляти і запроваджувати ефективну антиризикову стратегію, здатну мінімізувати негативний вплив ризиків і загроз зовнішнього і внутрішнього середовища на реалізацію тактичних і стратегічних планів функціонування та розвитку.

Закони побудови, функціонування та розвитку в сукупності виражають сутність системних об'єктів, що мають здатність до саморозвитку, однак «...кожна з перерахованих груп законів виражає сутність не у повному обсязі, а частково, в якомусь одному іiі відношенні» [14]. 3 огляду на це, розрізнення законів побудови, функціонування і розвитку має певне методологічне значення.

Закони побудови представлені структурними законами, які характеризують сутність системного об'єкта в аспекті його сьогочасної організації, у контексті стійкості та незмінності цієї системи (підприємства, організації, установи).

Закони функціонування розкривають сутність системного об'єкта в плані динамічності і внутрішньої рухливості (змінності) його організації в певний обмежений проміжок часу.

Закони розвитку виражають основні тенденції, рушійні сили, механізми і можливі шляхи перетворення цієї системи в нову, якісно відмінну, але генетично пов'язану 3 нею (рис. 3).

Сутність законів побудови, функиіонування та розвитку розглянемо приналежно до промислових підприємств та однією з ключових завдань нашого дослідження - управління фінансовими ризиками промислових підприємств.

Відповідно до нашого об'єкта дослідження - промислового підприємства як складної динамічної, ієрархічної і цілісної системи - закони побудови відображують внутрішні стійкі внутрішні зв'язки між елементами цієї системи та взаємозв'язки і взаємодію означених елементів та зазначеною системою загалом, а також із зовнішнім середовищем. Унаслідок такої взаємодії чисельні ризикоформуючі фактори спричинюють сукупність взаємопов'язаних ризиків, які в різних комбінаціях здійснюють відмінний за наслідками вплив на життєдіяльність промислового підприємства. 3 цих позицій закони побудови системи управління фінансовими ризиками відображують внутрішні стійкі зв'язки між фінансовими та іншими видами ризиків промислового підприємства, які виникають у ході його фінансової, операційної і інвестиційної діяльності, а також у випадку виникнення форс-мажорних обставин під впливом ризикоформуючих (збурюючих) факторів макро-, мезо- і макросередовища. До цієї групи законів належать закон цілісності (емерджентності), закон ієрархічності та закон пропорційності і композиції.

Закон иілісності (емерджентності) системи управління ризиками промислового підприємства проявляється у виникненні в нього «нових» інтеграційних якостей та не властивих йому компонентів і характеристик, що характеризує взаємозумовленість частини й цілого (зокрема, сукупного ризику та ризику окремих операцій, бізнес-процесів, видів і сфер діяльності промислового підприємства). 


\begin{tabular}{|c|c|c|}
\hline \multicolumn{3}{|c|}{$\begin{array}{c}\text { ЗАКОНИ ПОБУДОВИ, ФУНКЦІОНУВАННЯ І РОЗВИТКУ СИСТЕМНИХ ОБ'СКТІВ } \\
\text { (У контекті Управління фінансовими ризиками) }\end{array}$} \\
\hline \multicolumn{3}{|c|}{1121} \\
\hline \multicolumn{3}{|c|}{$\begin{array}{c}\text { ЗАКОНИ ПОБУДОВИ } \\
\text { представлені структурними законами, які характеризують сутність системного об’єкта в аспекті його сьогочасної організації, } \\
\text { у контексті стійкості та незмінності цієї системи (підприємства, організації, установи) }\end{array}$} \\
\hline $\begin{array}{c}\text { Закон иілісності (емерджентності) системи управління } \\
\text { ризиками промислового підприємства проявляється в } \\
\text { виникненні у нього «нових» інтеграційних якостей та не } \\
\text { властивих йому компонентів і характеристик, що } \\
\text { характеризує взаємозумовленість частини і цілого } \\
\text { (зокрема, сукупного ризику і ризику окремих операцій, } \\
\text { бізнес-процесів, видів і сфер діяльності промислового } \\
\text { підприємства) }\end{array}$ & $\begin{array}{c}\text { Закон ієрархічності визначає } \\
\text { упорядкування взаємодії між } \\
\text { рівнями організації складної } \\
\text { багаторівневої системи } \\
\text { управління фінансовими } \\
\text { ризиками в порядку від більш } \\
\text { значущого до менш значущого }\end{array}$ & $\begin{array}{c}\text { Закон пропориійності і композиції побудови } \\
\text { системи управління фінансовими ризиками } \\
\text { промислового підприємства вимагає збереження } \\
\text { пропорційності між власне системою та їі } \\
\text { елементами, що дозволяє за умови будь-яких } \\
\text { можливих змін на максимальному рівні і з } \\
\text { мінімальними фінансовими втратами реалізувати } \\
\text { потенціал, яким воно володіє }\end{array}$ \\
\hline
\end{tabular}

\section{ЗАКОНИ ФУНКЦІОНУВАННЯ}

розкривають сутність системного об’єкта в плані динамічності і внутрішньої рухливості (змінності) його організації в певний обмежений проміжок часу

Закон необхідної різноманітності - різноманітність $\quad$ Закон самоорганізації проявляється у складної системи вимагає управління, яке вирізняється достатнім різноманіттям, що допомагає виокремити та систематизувати причини недоліків у системі ризик-менеджменту та розробити шляхи підвищення ефективності управління, шо серед іншого досягається через створення відповідних здатності підприємства (організації, установи) протистояти руйнівним тенденціям, які особливо характерні для ненціям, які особливо характерні умов нестаціонарної економки, та адапту ватися до негативного впливу механізмів управління при необхідності свою структуру i зберігаючи цілісність

\section{ЗАКОН РОЗВИТКУ}

розкриває сутність системного об'єкта в плані динамічності і внутрішньої рухливості (змінності) його організації в даний обмежений відрізок часу і стверджує, що кожна система прагне досягти найбільшого сумарного потенціалу на всіх етапах свого життєвого циклу

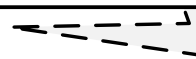

-ニニニー

система управління фінансовими ризиками, підпорядкована дії законів, знання і розуміння яких дозволить розуміти загальні і специфічні особливості становлення і функціонування зазначених систем, виокремлювати напрямки та характерні ознаки їх розвитку

Рис. 3. Закони побудови, функиіонування та розвитку системних об 'єктів у контексті управління фінансовими ризиками Джерело: розроблено автором на основі $[4 ; 6 ; 11 ; 14 ; 16 ; 17 ; 22 ; 23 ; 26 ; 29 ; 35]$. 
ФІНАНСОВІ РЕСУРСИ: ПРОБЛЕМИ ФОРМУВАННЯ ТА ВИКОРИСТАННЯ

У контексті управління фінансовими ризиками необхідно зазначити, що в процесі операційної, фінансової та інвестиційної діяльності промислового підприємства, а також виникнення форс-мажорних обставин виникають різні ризики, вплив яких різниться залежно від стадії життєвого циклу підприємства, галузі, продукту, який виготовляється. До того ж ступінь впливу одного ризику може змінюватись залежно від прояву інших ризиків, які можуть взаємопосилювати, або послаблювати один одного тобто 3 огляду на закон емерджентності, сукупний ризик функціонуючого промислового підприємства в умовах невизначеності не $\epsilon$ простою сумою впливу окремих ризиків, що виникають в різних сферах його діяльності. При цьому наслідки впливу сукупного ризику залежать від властивостей окремих ризиків як складових (структурних) елементів системи управління ризиками.

Упорядкування взаємодії між рівнями організації складної багаторівневої системи управління фінансовими ризиками в порядку від більш значущого до менш значущого визначається законом ієрархічності. При цьому ієрархія ризиків може суттєво змінюватись в умовах нестаціонарної економіки України під впливом збурюючи факторів зовнішнього і внутрішнього середовища.

Дотримання закону пропориійності й композицї побудови системи управління фінансовими ризиками промислового підприємства вимагає збереження пропорційності між власне системою та іiі елементами, що дозволяє за умови будь-яких можливих змін на максимальному рівні і з мінімальними фінансовими втратами реалізувати потенціал, яким воно володіє.

Розглянемо дію законів функціонування, а саме закону необхідної різноманітності, закону самоорганізації та закону самозбереження приналежно до системи управління фінансовими ризиками промислового підприємства.

Закон необхідної різноманітності (перший закон кібернетики, закон Ешбі) трактується так: різноманітність складної системи вимагає управління, яке вирізняється достатнім різноманіттям [1]. Згідно з цим законом зі зростанням складності бізнеспроцесів складність системи управління також повинна підвищуватися.

Використання означеного закону при вдосконаленні систем управління фінансовими ризиками промислового підприємства допомагає виокремити та систематизувати причини недоліків у системі ризик-менеджменту та розробити шляхи підвищення ефективності управління, що, серед іншого, досягається через створення відповідних механізмів управління.

Закон самоорганізації проявляється у здатності підприємства (організації, установи) протистояти руйнівним тенденціям, які особливо характерні для умов нестаціонарної економки, та адаптуватися до негативного впливу зовнішніх збурюючих факторів, змінюючи у разі необхідності свою структуру і зберігаючи цілісність. Тобто у функціонуючих промислових підприємств, з одного боку, завжди має місце прагнення до зростання диференціації (тобто поділу розчленування чого-небудь на окремі різнорідні елементи, (наприклад, створення самостійних структурних підрозділів) [27], розпаду, ентропії (як відхилення системи чи іiі окремої ланки від еталонного (нормального, очікуваного) стану, що здатне спричинити зниження темпів розвитку системи, погіршення ефективності іï функціонування і т. ін.).

3 іншого боку, здатність системи до самоорганізації спроможне позитивно впливати на еволюційні процеси розвитку промислового підприємства за рахунок підвищення рівня організації і управління підсистем розвитку промислового підприємства до яких можна віднести і систему управління фінансовими ризиками, від ефективності якої залежить результативність діяльності промислового підприємства загалом. 
ФІНАНСОВІ РЕСУРСИ: ПРОБЛЕМИ ФОРМУВАННЯ ТА ВИКОРИСТАННЯ

Закон самозбереження припускає, що будь-яка система та ії окремі елементи в умовах коливання зовнішнього і внутрішнього середовища, змін характеру діяльності та якості управління, наявності фінансових, трудових, матеріальних, енергетичних та інших видів ресурсів прагне зберегти себе як ціле.

Врахування закону самозбереження у контексті управління фінансовими ризиками потребує розуміння того, що прагнення до «цілого збереження» може стримувати розвиток системи промислового підприємства загалом та іiї структурного елемента - системи управління ризиками, спричинювати відмову підприємства від застосування інноваційних технологій, методів і форм управління, що наблизить стадію спаду життєвого циклу підприємства. Одночасно прискорений та/або не забезпечений достатніми ресурсами процес функціонування та розвитку може привести тільки до «тимчасового успіху».

Закон розвитку стверджує, що кожна система прагне досягти найбільшого сумарного потенціалу на всіх етапах свого життєвого циклу. 3 огляду на це, дослідження видів фінансових ризиків на всіх стадіях життєвого циклу продукту / підприємства галузі та їхньої поведінки під впливом змін факторів зовнішнього і внутрішнього середовища обгрунтовує доцільність дослідження циклічності ризиків, що дозволить створити необхідні теоретико-прикладні основи для забезпечення максимально можливої ефективності управління фінансовими ризиками загалом.

Промислове підприємство як складна ієрархічна й динамічна система, що має у своєму складі різного роду підсистеми, до яких можна віднести й систему управління фінансовими ризиками, підпорядковано дії законів, знання і розуміння яких дозволить розуміти загальні та специфічні особливості становлення і функціонування зазначених систем, виокремлювати напрями та характерні ознаки їхнього розвитку.

Проблема розвитку системних утворень різних видів, і промислових підприємств зокрема, як системи та їхніх структурних елементів (підсистем різного рівня) вивчається в межах теорії управління, стратегічного менеджменту, фінансового менеджменту, ризикменеджменту, антикризового менеджменту, інноваційного та інвестиційного менеджменту.

Кожен $з$ вказаних напрямів стосується окремих аспектів становлення, функціонування та розвитку промислових підприємств, що мають на меті досягнути максимальної результативності діяльності з мінімальними втратами фінансових та інших видів ресурсів, що, у свою чергу, залежить від здатності даних суб'єктів господарювання розробляти і реалізувати ефективну антиризикову політику, що відбувається шляхом запровадження зваженого механізму управління ризиками.

Отже, закони побудови, функціонування та розвитку економічних систем і процесів можна розглядати й як загальні закони управління такими системами і процесами.

Закони ризик-менеджменту, на нашу думку, необхідно розглядати комплексно, тобто в тісному взаємозв'язку і взаємодії із загальними, специфічними і спеціальними законами управління (рис. 4).

Загальні закони управління фінансовими ризиками відображають загальні причинно-наслідкові зв'язки в управлінській діяльності. Закони управління визначають особливості менеджменту на всіх стадіях життєвого циклу промислового підприємства, а їх розуміння адміністрацією підприємства впливає на результативність розробки і реалізації його тактичних і стратегічних планів, орієнтованих зокрема на забезпечення стійкого соціально-економічного, інноваційно-інвестиційного і техніко-технологічного розвитку. До таких законів можна віднести описані вище закони емерджентності, ієрархічності, необхідної різноманітності, пропорційності і композиції, самоорганізації та закони самозбереження і розвитку. 


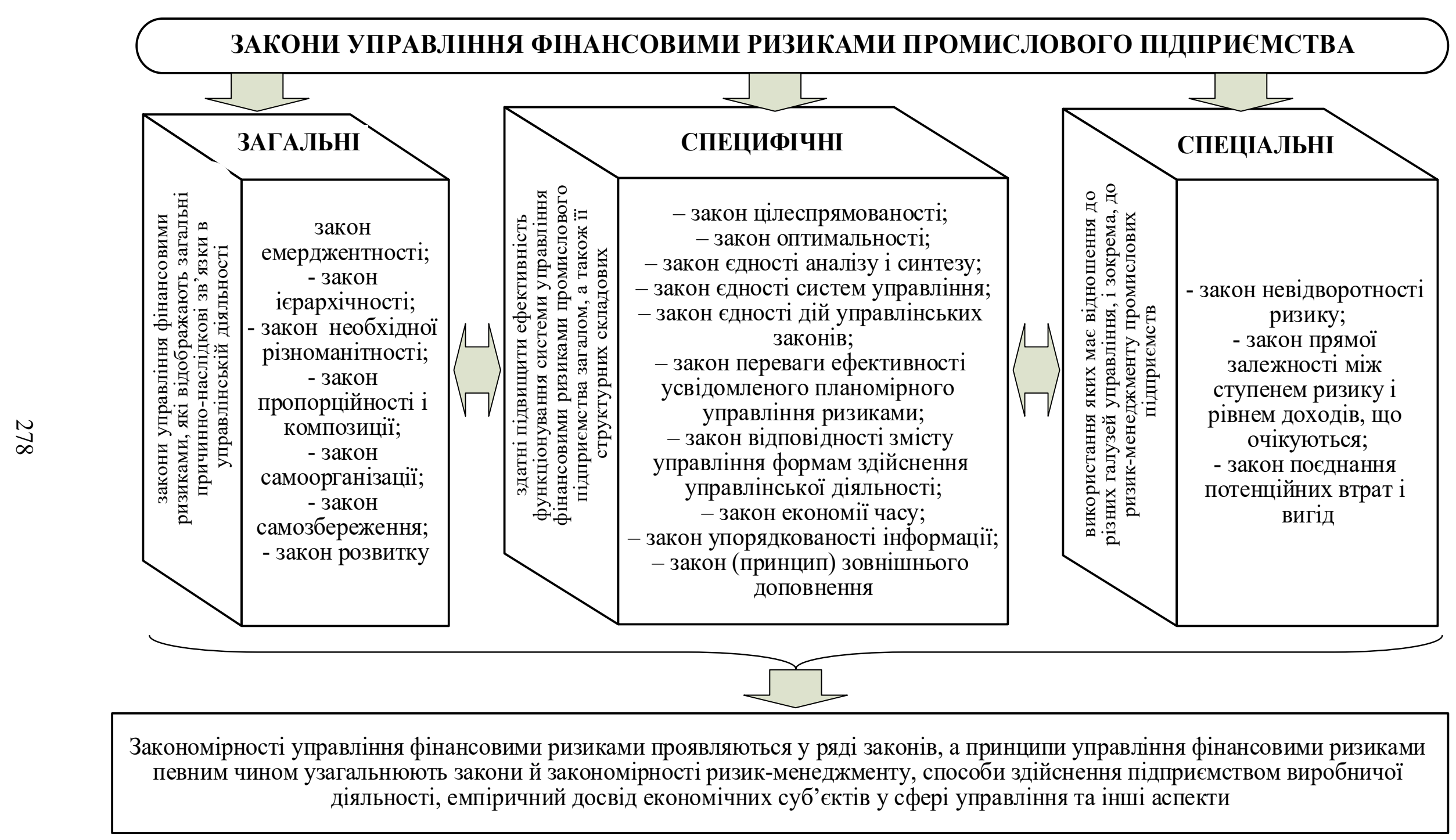


ФІНАНСОВІ РЕСУРСИ: ПРОБЛЕМИ ФОРМУВАННЯ ТА ВИКОРИСТАННЯ

До спещифічних законів, які здатні підвищити ефективність функціонування системи управління фінансовими ризиками промислового підприємства загалом, а також іiі структурних складових, вважаємо доцільним віднести:

- закон иілеспрямованості, який має на увазі, що будь-який процес управління має свою мету. Зокрема, процес управління фінансовими ризиками спрямований на мінімізацію фінансових втрат у діяльності промислового підприємства в умовах невизначеності зовнішнього і внутрішнього середовища його функціонування;

- закон оптимальності - сутність якого полягає в тому, що управління повинно бути найліпшим з погляду врахування наявності наявних обмежень і загроз зовнішнього i внутрішнього середовища;

- закон єдності аналізу i синтезу - будь-яка система прагне налаштуватись на найбільш економічний режим функціонування шляхом застосування аналізу й синтезу, що вимагає невпинного удосконалення проведення процесів, які властиві певній системі;

- закон єдності систем управління відносно ризик-менеджменту передбачає, що система управління фінансовими ризиками є ієрархічною і підпорядковується загальним вимогам до таких систем, орієнтується на досягнення тактичних і стратегічних цілей виконує встановлені перед промисловим підприємством завдання;

- закон єдності дій управлінських законів передбачає, що робота системи управління фінансовими ризиками не повинна суперечити ключовим рішенням у сфері управління промисловим підприємством;

- закон переваги ефективності усвідомленого планомірного управління ризиками доводить, що важливо «прорахувати» можливі наслідки прийняття ризиків і застосовувати управляючі дії, комбінуючи при цьому різні спеціальні способи і методи управління;

- закон відповідності змісту управління формам здійснення управлінської діяльнос$m i$ проявляється в такому: остаточні рішення відносно прийняття, передачі чи уникнення ризику приймаються власниками промислового підприємства, оскільки саме вони беруть на себе фінансові втрати внаслідок негативного прояву ризиків в ході здійснення суб'єктом господарювання всіх видів діяльності;

- закон економії часу у контексті управління фінансовими ризиками полягає у одержанні максимально можливого результату щодо попередження негативних подій за мінімальної кількості часу;-закон упорядкованості інформащії можна сформулювати таким чином: чим більшою інформованістю про поточний і перспективний стан внутрішнього і зовнішнього середовища володіє промислове підприємство, тим більша ймовірність уникнення та/або мінімізації негативного впливу фінансових ризиків на його життєдіяльність, а отже забезпечення нормального функціонування. Це вимагає від промислового підприємства створення, розвитку й постійного вдосконалення умов нормального функціонування системи збору, розподілу, обробки, передачі і використання інформації щодо особливостей змін і активізації загроз зовнішнього і внутрішнього середовища необхідної для прийняття зважених управлінських рішень у сфері ризик-менеджменту;

Крім того до таких законів на нашу думку є сенс віднести закон (принизип) зовніинього доповнення, сформульований С. Біром так: «...будь-яка система управління має потребу у «чорній скрині» - певних резервах, за допомогою яких компенсується неврахований вплив зовнішнього і внутрішнього середовища» [6].

До категорії спеціальних законів управління, використання яких має відношення до різних галузей управління, і зокрема, до ризик-менеджменту промислових підприємств пропонуємо віднести: закон невідворотності ризику, закон прямої залежності між ступенем ризику й рівнем доходів, щуо очікуються, закон поєднання потенційних втрат і вигід. 
ФІНАНСОВІ РЕСУРСИ: ПРОБЛЕМИ ФОРМУВАННЯ ТА ВИКОРИСТАННЯ

Сутність закону невідворотності ризику промислового підприємства полягає в тому, що діяльність окресленого суб'єкта підприємництва завжди супроводжується фінансовими та іншими видами ризиків, що спричинюються зовнішнім і внутрішнім середовищем. Необхідно зазначити, що повною мірою уникнути ризиків неможливо, а отже, їх необхідно сприймати як об'єктивний елемент системи управління ризиками.

Закон прямої залежності між ступенем ризику і рівнем доходів, щзо очікуються доводить: чим більше ступінь ризику при здійсненні промисловим підприємством своєї діяльності (операційної, інвестиційної, фінансової) або виконанні певної операції, тим вище рівень доходів, що плануються від відповідної операції чи діяльності і навпаки.

Закон поєднання потенційних втрат $і$ вигід полягає у тому, що практично в будьяких ризикових ситуаціях потенційна можливість втрат чи збитків поєднується з потенційною можливістю отримання додаткових доходів.

Закономірності управління фінансовими ризиками проявляються у ряді законів, а принципи управління фінансовими ризиками певним чином узагальнюють закони й закономірності ризик-менеджменту, способи здійснення підприємством виробничої діяльності, емпіричний досвід економічних суб'єктів у сфері управління та інші аспекти.

Проведені автором теоретико-прикладні дослідження дозволили сформулювати деякі окремі закономірності ризик-менеджменту промислових підприємств. А саме:

- висока фінансова стійкість промислових підприємств віддзеркалює низький ступінь сукупного рівня фінансового ризику;

- сукупний рівень фінансового ризику не є простою алгебраїчною сумою фінансових витрат на реалізацію анти ризикових заходів і суми збитків від прояву ризиків в діяльності промислового підприємства;

- своєчасна розробка та запровадження анти ризикових заходів сприяє уникненню додаткових збитків в діяльності промислового підприємства;

- зростання фінансових втрат від прояву фінансових та інших видів ризиків знижує бухгалтерську та економічну вартість промислового підприємства.

Висновки та пропозиції. Розуміння законів і закономірностей управління фінансовими ризиками дає можливість промисловим підприємствам зрозуміти існуючі зв'язки між наявними структурними елементами й підсистемами такої складної ієрархічної системи, як промислове підприємство, що сприяє забезпеченню ефективності вирішення нагальних проблем і подоланню численних загроз спричинених факторами зовнішнього i внутрішнього середовища. У процесі проведеного дослідження було розкрито змістовну сутність універсальних, загальних і часткових законів, законів, що є описовими і пояснюючими, законів, які є статистичними і динамічними, законів, які носять фундаментальний та прикладний характер, є феноменологічними і есенціальними, а також законів побудови, функціонування і розвитку систем. Визначено роль і місце законів управління в загальній системі законів, сформульовано сутність законів управління фінансовими ризиками промислових підприємств.. 3'ясовано, що в процесі пошуку шляхів мінімізації ймовірних фінансових втрат від прояву різних видів фінансових ризиків промислове підприємство повинно дотримуватись певних правил, тобто принципів управління ризиками, дослідження яких стане предметом подальших наукових досліджень.

\section{Список використаних джерел}

1. Ashby W.R. Introduction to Cybernetics, Chapman \& Hall, 1956. URL: http://pcp.vub.ac.be/ books/IntroCyb.pdf.

2. Braunerhjelm P., Feldman M. Cluster Genesis: Technology Based Industrial Development. Oxford: Oxford University Press. 2006. 353 p.

3. Committee of Sponsoring Organizations of the Treadway Commission. Enterprise Risk Management Integrating with Strategy and Performance. URL: https://www.coso.org/Documents/ 2017-COSO-ERM-Integrating-with-Strategy-and-Performance-Executive-Summary.pdf.

4. Амосов Н. М. Моделирование сложных систем. Киев : Наукова думка, 1968. 81 с. 
ФІНАНСОВІ РЕСУРСИ: ПРОБЛЕМИ ФОРМУВАННЯ ТА ВИКОРИСТАННЯ

5. Андерсен Б. Бизнес-процессы. Инструменты совершенствования / пер. с англ. С. В. Ариничева; науч. ред. Ю. П. Адлер. Москва : РИА «Стандарты и качество», 2005. 272 с.

6. Бир С. Кибернетика и управление производством. Москва : Наука, 1965. 391 с.

7. Валуєв Ю. Б. Процесно-функціональне управління промисловим підприємством : монографія. Одеса : Ін-т пробл. ринку та екон.-екол. дослідж. НАН України, 2011. 296, [2] с.

8. Володькіна М. В. Організація управління промисловим підприємством : навч. посіб. Київ : КНЕУ, 2011. 318 с.

9. Дрещинский В. А. Основы научных исследований : учебник для СПО. 2-е изд., пер. и доп. Москва : Издательство Юрайт, 2018. 274 с.

10. Злобина Н. В., Пешкова Г. Ю. Современные тенденции управления рисками: взаимосвязь между риском, стратегией и стоимостью компании. Инновационная экономика: перспективы развития и совершенствования. 2018. № 8 (34). C. 128-133. URL: https://cyberleninka.ru/article/n/sovremennye-tendentsii-upravleniya-riskami-vzaimosvyaz-mezhduriskom-strategiey-i-stoimostyu-kompanii/viewer.

11. Исследования по общей теории систем : сб. переводов. Москва : Прогресс, 1969. 520 с.

12. Капустина Н. В., Кузнецов Ю. В. Принципы исследования системы управления рисками. Вестник МГТУ. 2010. Т. 13, № 1. С. 15-21. URL: https://cyberleninka.ru/article/n/printsipyissledovaniya-sistemy-upravleniya-riskami/viewer.

13. Кокинз Г. Управление результативностью: Как преодолеть разрыв между объявленной стратегией и реальными процессами. Москва : Альпина Бизнес Букс, 2007. 315 с.

14. Константинов Ф. В. Объективная диалектика. Законы строения, функционирования и развития. URL: https://fil.wikireading.ru/17652.

15. Коршунова Н. Л., Литвинов В. П., Рац М. В., Котельников С. И., Матьяш О. И. Понятия фундаментального и прикладного и их приложение в науке. Управление наукой и наукометрия. 2013. URL: https://cyberleninka.ru/article/n/ponyatiya-fundamentalnogo-i-prikladnogo-iih-prilozhenie-v-nauke.

16. Новая философская энциклопедия : в 4 т / Ин-т философии РАН, Нац. общ.-научн. фонд; Научно-ред. совет: предс. В. С. Стёпин, заместители предс.: А. А. Гусейнов, Г. Ю. Семигин, уч. секр. А.П. Огурцов. Москва : Мысль, 2010. Т. ІІ. 634 с.

17. Новиков Д. А. Законы, закономерности и принципы управления. Иновации в менеджменте. 2016. № 7. С. 44-53.

18. Новиков Д. А. Методология управления. Москва : Либроком, 2011. 128c.

19. Осипов В. Е. Динамические и статистические законы в системе теоретического знания. Современные технологии. Системный анализ. Моделирование. 2010. URL: https://cyberleninka.ru/article/n/dinamicheskie-i-statisticheskie-zakony-v-sisteme-teoreticheskogoznaniya/viewer.

20. Панченко О. І. Типологізація фінансових ризиків як основа організації їх страхового захисту. Бізнес інформ. 2019. № 3. С. 350-357.

21. Портер М. Преимущества стран в конкурентной борьбе. Москва : Прогресс, 1990. 370 с.

22. Прангишвили И. В. Системный подход и общесистемные закономерности. Москва : СИНТЕГ, 2000. 528 с.

23. Разумовский О. С. Закон (Словарная статья). URL: https://dia-logic.livejournal.com/ 44261.html.

24. Репин В., Елиферов В. Процессный подход к управлению. Моделирование бизнеспроцессов. Москва : Манн, Иванов и Фербер, 2013. 544 с.

25. Репин В. В., Елиферов В. Г. Процессный подход к управлению. Воронеж : Машиностроение, 2004. $408 \mathrm{c}$.

26. Сильва Х., Стоун Р.Б. Искусство управления по методу Сильва: пер с англ. Минск : ООО «Попурри», 1999. $288 \mathrm{c.}$

27. Словник української мови. Академічний тлумачний словник (1970-180) : в 11 т. Київ : Наукова думка, 1971. Т. 2. C. 289. URL: http://sum.in.ua/s/dyferenciacija.

28. Сніщенко Р. Г. Математичні методи дослідження ризиків. Економіка і регіон. 2014. № 1.

C. 144-149. URL: http://nbuv.gov.ua/UJRN/econrig_2014_1_23.

29. Спиркин А. Г. Философия : учебник. 2-е изд. Москва : Гардарики, 2006. 736 с. 
ФІНАНСОВІ РЕСУРСИ: ПРОБЛЕМИ ФОРМУВАННЯ ТА ВИКОРИСТАННЯ

30. Технології управління сучасним промисловим підприємством : монографія [Г. В. Козаченко та ін.] ; за заг. ред. проф. Г. В. Козаченко. Луганськ : Промдрук, 2013. 389 с.

31. Фомичев А. Н. Риск-менеджмент : учебник для бакалавров. 4-е изд. Москва : Издательско-торговая корпорация «Дашков и $\mathrm{K}^{\circ} », 2016.372$ с.

32. Шарапов В. М., Шарапова Е. В. Универсальные технологии управления. Москва : Техносфера, 2006. 496 c.

33. Шеер А.-В. Моделирование бизнес-процессов : пер. с англ. 2-е изд., перераб. и доп. Москва : Весть-МетаТехнология, 2000. 222 с.

34. Шишкіна О. В. Концептуальні основи визначення схильності до ризику промислових підприємств. Науковий вісник Ужгородського національного університету: Серія: Міжнародні економічні відносини та світове господарство. 2019. Вип. 28, ч. 2. С. 153-157.

35. Шишкіна О. Термінологічні проблеми пізнання природи фінансового ризику. Проблеми і перспективи економіки та управління. 2019. № 1 (17). С. 253-264.

36. Шумпетер И. А. Теория экономического развития. Москва :Экономика, 1982. 141c.

37. Экономико-социологический словарь / сост.: Г. Н. Соколова, О. В. Кобяк ; науч. ред. Г. Н. Соколова. Минск : Беларус. навука, 2013. 615 с.

38. Burlutskiy S. V., Burlutska S. V., Marhasova V. G., Sakun O. S. (2019). The relationship between short-term fluctuations and stages of economic cycle: The case of Ukraine. Espacios. 2019. Vol. 40, No. 10. URL: http://www.revistaespacios.com/a19v40n10/a19v40n10p10.pdf.

\section{References}

1. Ashby, W. R. (1956). Introduction to Cybernetics, Chapman \& Hall. Retrieved from http://pcp.vub.ac.be/books/IntroCyb.pdf.

2. Braunerhjelm, P., Feldman, M. (2006). Cluster Genesis: Technology Based Industrial Development. Oxford: Oxford University Press.

3. Committee of Sponsoring Organizations of the Treadway Commission. Enterprise Risk Management Integrating with Strategy and Performance. Retrieved from https:/www.coso.org/ Documents/2017-COSO-ERM-Integrating-with-Strategy-and-Performance-Executive-Summary.pdf.

4. Amosov, N. M. (1968). Modelirovanie slozhnykh sistem [Modeling of complex systems]. Kyev: Naukova dumka [in Russian].

5. Andersen, B. (2005). Biznes-protsessy. Instrumenty sovershenstvovaniia [Business processes. Improvement tools] (Trans. S. V. Arynycheva; scientific ed. Yu. P. Adler). Moscow: RIA «Standarty i kachestvo» [in Russian].

6. Bir, S. (1965). Kibernetika i upravlenie proizvodstvom [Cybernetics and Production Management]. Moscow: Nauka [in Russian].

7. Valuiev, Yu. B. (2011). Protsesno-funktsionalne upravlinnia promyslovym pidpryiemstvom [Process-functional management of industrial enterprise]. Odesa: In-t probl. rynku ta ekon.-ekol. doslidzh. NAN Ukrainy [in Ukrainian].

8. Volodkina, M. V. (2011). Orhanizatsiia upravlinnia promyslovym pidpryiemstvom [Organization of industrial enterprise management]. Kyiv: KNEU [in Ukrainian].

9. Dreshchynskyi, V. A. (2018). Osnovy nauchnykh issledovanii: uchebnyk dlia SPO [Fundamentals of scientific research: a textbook for SPO]. (2 ${ }^{\text {nd }}$ ed.). Moscow: Izdatelstvo Yurait [in Ukrainian].

10. Zlobina, N. V., Peshkova, G. Iu. (2018). Sovremennye tendentsii upravleniia riskami: vzaimosviaz mezhdu riskom, strategiei i stoimostiu kompanii [Current trends in risk management: the relationship between risk, strategy and company value]. Innovatsionnaia ekonomika: perspektivy razvitiia $i$ sovershenstvovaniia - Innovative economy: prospects for development and improvement, 8 (34), 128-133. Retrieved from https://cyberleninka.ru/article/n/sovremennyetendentsii-upravleniya-riskami-vzaimosvyaz-mezhdu-riskom-strategiey-i-stoimostyukompanii/viewer.

11. Issledovaniia po obshchei teorii sistem: sbornik perevodov [Studies in the general theory of systemsa collection of translations]. (1969). Moscow: Progress [in Russian].

12. Kapustina, N. V., Kuznetsov, Iu. V. (2010). Printsipy issledovaniia sistemy upravleniia riskami [Principles of research of a risk management system]. Vestnyk MHTU - Bulletin of MSTU, 13 (1), $15-21$. Retrieved from https://cyberleninka.ru/article/n/printsipy-issledovaniya-sistemy-upravleniya-riskami/viewer. 
ФІНАНСОВІ РЕСУРСИ: ПРОБЛЕМИ ФОРМУВАННЯ ТА ВИКОРИСТАННЯ

13. Kokinz, H. (2007). Upravlenie rezultativnostiu: Kak preodolet razryv mezhdu obiavlennoi strategiei i realnymi protsessami [Performance Management: How to bridge the gap between the announced strategy and real processes]. Moscow: Alpina Biznes Buks [in Russian].

14. Konstantinov, F. V. (1981). Obektivnaia dialektika [Objective dialectics]. Moscow: Mysl. Retrieved from https://fil.wikireading.ru/17652.

15. Korshunova, N. L., Litvinov, V. P., Rats, M. V., Kotelnikov, S. I., Matiash, O. I. (2013). Poniatiia fundamentalnogo i prikladnogo i ikh prilozhenie $\mathrm{v}$ nauke [The concepts of fundamental and applied and their application in science]. Upravlenie naukoi i naukometriia-Management of science and scientometrics, 14, 67-81. Retrieved from https://cyberleninka.ru/article/n/ponyatiyafundamentalnogo-i-prikladnogo-i-ih-prilozhenie-v-nauke.

16. Novaia filosofskaia entsiklopediia [A new philosophical encyclopedia]. (2010). (Vols. 1-4, Vol. 2). Moscow: Mysl [in Russian].

17. Novikov, D. A. (2016). Zakony, zakonomernosti i printsipy upravleniia [Laws, laws and principles of management]. Inovatsii v menedzhmente - Innovation in management, 7, 44-53 [in Russian].

18. Novikov, D. A. (2011). Metodologiia upravleniia [Management methodology]. Moscow: Librokom [in Russian].

19. Osipov, V. E. (2010). Dinamicheskie i statisticheskie zakony v sisteme teoreticheskogo znaniia [Dynamic and statistical laws in the system of theoretical knowledge. Modern technologies]. Sovremennue tekhnologii. Sistemnyi analiz. Modelirovanie - System analysis. Modeling, 4 (28), 212-220. Retrieved from https://cyberleninka.ru/article/n/dinamicheskie-i-statisticheskie-zakony-vsisteme-teoreticheskogo-znaniya/viewer.

20. Panchenko, O. I. (2019). Typolohizatsiia finansovykh ryzykiv yak osnova orhanizatsii yikh strakhovoho zakhystu [The Typology of Financial Risks as a Basis of Organization of Their Insurance Protection]. Biznes inform - Business Inform, 3, 350-357 [in Ukrainian].

21. Porter, M. (1990). Preimushchestva stran v konkurentnoi borbe [Advantages of countries in competition]. Moscow: Progress [in Russian].

22. Prangishvili, I. V. (2000). Sistemnyi podkhod i obshchesistemnye zakonomernosti [System approach and system-wide laws]. Moscow: SINTEH [in Russian].

23. Razumovskii, O. S. Zakon (Slovarnaia statia) [Law (Dictionary article)]. https://dialogic.livejournal.com. Retrieved from https://dia-logic.livejournal.com/44261.html.

24. Repin, V., Eliferov, V. (2013). Protsessnyi podkhod k upravleniiu. Modelirovanie biznesprotsessov [Process approach to management. Modeling business processes]. Moscow: Mann, Ivanov i Ferber [in Russian].

25. Repin, V. V., Eliferov, V. G. (2004). Protsessnyi podkhod k upravleniiu [Process approach to management]. Voronezh: Mashinostroenie [in Russian].

26. Silva, Kh., Stoun, R. B. (1999). Iskusstvo upravleniia po metodu Silva [The art of control by the method of Silva]. Minsk: OOO «Popurri» [in Russian].

27. Slovnyk ukrainskoi movy. Akademichnyi tlumachnyi slovnyk (1970-180) [Dictionary of the Ukrainian language. Academic Interpretive Dictionary (1970-180)]. (Vols. 11, Vol. 2) (1971). Retrieved from http://sum.in.ua/s/dyferenciacija].

28. Snishchenko, R. H. (2014). Matematychni metody doslidzhennia ryzykiv [Mathematical methods of risk research]. Ekonomika i rehion - Economy and region, 1, 144-149. Retrieved from http://nbuv.gov.ua/UJRN/econrig_2014_1_23.

29. Spirkin, A. H. (2006). Fylosofiia [Philosophy]. (2 $2^{\text {nd }}$ ed.). Moscow: Gardariki [in Russian].

30. Kozachenko, H. V. (Ed.). (2013). Tekhnolohii upravlinnia suchasnym promyslovym pidpryiemstvom [Technologies of management of modern industrial enterprise]. Luhansk: Promdruk [in Ukrainian].

31. Fomichev, A. N. (2016). Risk-menedzhment [Risk management]. (4 ${ }^{\text {th }}$ ed.). Moscow: Izdatelsko-torhovaia korporatsiia «Dashkov y Ko» [in Russian].

32. Sharapov, V. M., Sharapova, E. V. (2006). Universalnye tekhnologii upravleniia [Universal control technologies]. Moscow: Tekhnosfera [in Russian].

33. Sheer, A.-V. (2000). Modelirovanie biznes-protsessov [Business Process Modeling]. ( $2^{\text {nd }}$ ed.). Moscow: Vest-MetaTekhnologiia [in Russian]. 
ФІНАНСОВІ РЕСУРСИ: ПРОБЛЕМИ ФОРМУВАННЯ ТА ВИКОРИСТАННЯ

34. Shyshkina, O. V. (2019). Kontseptualni osnovy vyznachennia skhylnosti do ryzyku promyslovykh pidpryiemstv [Conceptual bases of determination of risk aversion of industrial enterprises]. Naukovyi visnyk Uzhhorodskoho natsionalnoho universytetu: Seriia: Mizhnarodni ekonomichni vidnosyny ta svitove hospodarstvo - Uzhgorod National University Scientific Bulletin: Series: International Economic Relations and the World Economy, 28 (2), 153-157 [in Ukrainian].

35. Shyshkina, O. (2019). Terminolohichni problemy piznannia pryrody finansovoho ryzyku [Terminological problems of knowledge of nature of financial risk]. Problemy $i$ perspektyvy ekonomiky ta upravlinnia - Problems and prospects of economics and management, 1 (17), 253-264 [in Ukrainian].

36. Shumpeter, I. A. (1982). Teoriia ekonomicheskogo razvitiia [Theory of economic development]. Moscow: Ekonomika [in Russian].

37. Sokolova, H. N., Kobiak, O. V., Sokolova, H. N. (Ed.) (2013). Ekonomiko-sotsiologicheskii slovar [Economic and Sociological Dictionary]. Minsk: Belarus. Navuka [in Russian].

38. Burlutskiy, S. V., Burlutska, S. V., Marhasova, V. G., Sakun, O. S. (2019). The relationship between short-term fluctuations and stages of economic cycle: The case of Ukraine. Espacios, 40 (10). Retrieved from http://www.revistaespacios.com/a19v40n10/a19v40n10p10.pdf.

Шишкіна Олена Вікторівна - кандидат економічних наук, доцент, доцент кафедри фінансів, банківської справи та страхування, Чернігівський національний технологічний університет (вул. Шевченка, 95, м. Чернігів, 14035, Україна).

Шишкина Елена Викторовна - кандидат экономических наук, доцент, доцент кафедры финансов, банковского дела и страхования, Черниговский национальный технологический университет (ул. Шевченко, 95, г. Чернигов, 14035, Украина).

Shyshkina Olena - PhD in Economics, Associate Professor, Associate Professor of Department of Finance, Banking and Insurance, Chernihiv National University of Technology (95 Shevchenka Str., 14035 Chernihiv, Ukraine).

E-mail: shyshkina.olena.v@gmail.com

ORCID: http://orcid.org/0000-0002-8946-1027

ResearcherID: F-3208-2014 